A N N A LE S

UNIVERSITATIS MARIAE CURIE-SKŁODOWSKA

LUBLIN - POLONIA

VOL. XXXV

SECTIO FF

$2-2017$

\title{
Lustra $\mathrm{i}$ inne
}

Mirrors and Others

Prezentowany tom poświęcony współczesnym zjawiskom kultury organizuje metafora luster, które tworzy otaczająca nas rzeczywistość - literacka, plastyczna, muzyczna czy architektoniczna - owym lustrem sama dla siebie się staje, w nim się przegląda i kreuje kolejne odbicia, zwielokrotnienia, multiplikacje. Nie są to działania, jak można by było sądzić, charakterystyczne wyłącznie dla kultury masowej, gdyż w takim samym stopniu podlega im sztuka z kręgu elitarnego. Natomiast obie - generalnie rzecz ujmując - obecnie czynią z zapożyczeń, odwołań, powieleń raczej cnotę niż przywarę. Dla współczesnej literatury intertekstualne odniesienia są tak naturalne i powszechne, iż właściwie oczywiste. Stanowią one o semantycznym i estetycznym bogactwie utworu, pomnażają znaczenia, zwielokrotniają punkty odniesienia, poszerzają możliwości interpretacyjne.

Mimo iż niniejszy tom poświęcony jest zjawiskom współczesnym, to zwielokrotnienia i tworzenie lustrzanych odbić - chociaż nie w ten sposób określane - nie są w kulturze niczym nowym. Wszyscy wielcy twórcy, od Homera począwszy, byli świadomi powtarzalności, nawiązań, odwołań tworzących zjawiska sztuki i kultury. Budowanie własnej opowieści w izolacji, bez świadomości tego, co przed nią i tego, co wokół niej jest niemożliwe.

Jak słusznie zauważa Stephan Greenblatt:

[...] mimo naszego romantycznego kultu oryginalności większość artystów to utalentowani twórcy wariantów znanych tematów. [...] I tak Dickens tworzył przemyślne przeróbki melodramatycznej szmiry swych czasów, Szekspir zapożyczył większość fabuł i wielu bohaterów z popularnych opowieści i powszechnie wykorzystywanych jako źródła pism historycznych, a Spencer przeniósł na grunt własnej kultury historie opowiedziane, i to po mistrzowsku, przez włoskich poetów Ariosta i Tassa (Greenblatt, 2006:152). 
Pomimo stałej obecności tego tematu $\mathrm{w}$ teorii i krytyce literatury oraz sztuki są to nadal ważkie, aktualne zagadnienia, którym próbujemy się przyjrzeć $\mathrm{w}$ niniejszym tomie, koncentrując się na kwestiach związanych z budowaniem „lustrzanych odbić” we współczesnej kulturze. Z konieczności postawione też musiały być pytania o relacje pomiędzy oryginałem i jego odbiciem, o granice wykorzystywania pierwowzoru, jeśli w ogóle takowe granice istnieją.

Artykuły zebrane w prezentowanym numerze „Annales” mierzą się z tymi aktualnymi, acz niewątpliwie trudnymi, zagadnieniami. Autorzy poszczególnych prac skupiają się na wybranych technikach odwołujących się do metody „budowania luster" lub prezentują szersze spektrum działań literackich i pozaliterackich mieszczących się w sferze wpływów tego, co oryginalne i tego, co powtórzone. Panoramiczne ujęcia i szczegółowe analizy obejmują różnogatunkowe formy wypowiedzi (reportaż, literatura cyfrowa, biografia, fotokolaże) z obszaru różnych sztuk (literatura, filozofia, film, plastyka, cyberkultura, fotografia, rzeźba), co daje możliwość wieloaspektowego oglądu oryginalności i powtórzeń we współczesnej kulturze.

Redaktorzy

BIBLIOGRAFIA

Greenblatt, S. (2006). Poetyka kulturowa. Pisma wybrane. Przeł. A. Rajca-Salata. Kraków: Universitas. 